男子大学生における健康関連 QOL尺度と体温の日内変動特性および生活習慣の関連性 西村 一樹 ${ }^{1}$, 山口 英峰, 野瀬 由佳 ${ }^{3}$, 吉岡 哲 $^{4}$, 長㟝 浩爾 ${ }^{5}$, 小野寺 昇 $^{6}$, 高本 登 $^{7}$

\title{
The relationship between health-related quality of life measures, daily rhythm of oral temperature and lifestyle in young men
}

\author{
Kazuki Nishimura ${ }^{1}$, Hidetaka Yamaguchi ${ }^{2}$, Yuka Nose $^{3}$, Akira Yoshioka $^{4}$, Koji Nagasaki $^{5}$, \\ Sho Onodera ${ }^{6}$ and Noboru Takamoto ${ }^{7}$
}

\begin{abstract}
${ }^{1}$ 広島工業大学地球環境学科, ₹731-5193 広島県広島市佐伯区三宅 2-1-1 (Department of Global Environment Studies, Hiroshima Institute of Technology, 2-1-1 Miyake, Saeki-ku, Hiroshima-city, Hiroshima 731-5193, Japan)

2吉備国際大学スポーツ社会学科，テ716-8508 岡山県高梁市伊賀町 8 (Department of Sports Social Management, Kibi International University, 8 Igamachi, Takahashi-city, Okayama 716-8508, Japan)

3 安田女子大学管理栄養学科, 干731-0153 広島県広島市安佐南区安東6-13-1 (Department of Nutritional Sciences, Yasuda Women's University, 6-13-1 Yasuhigashi, Asaminami-ku, Hiroshima-city, Hiroshima 731-0153, Japan)

${ }^{4}$ 岡山大学スポーツ教育センター，７700-8530 岡山県岡山市北区津島中2-1-1 (Interactive Sport Education Center, Okayama University, 2-1-1 Tsushima-naka, Kita-ku, Okayama-city, Okayama 700-8530, Japan)

5 広島工業大学食品生命科学科, 干731-5193 広島県広島市佐伯区三宅2-1-1 (Department of Food Sciences and Biotechnology, Hiroshima Institute of Technology, 2-1-1 Miyake, Saeki-ku, Hiroshima-city, Hiroshima 731-5193, Japan)

${ }^{6}$ 川崎医療福祉大学健康体育学科，７701-0193 岡山県倉敷市松島 288 (Department of Health and Sports Science, Kawasaki University of Medical Welfare, 288 Matsushima, Kurashiki-city, Okayama 701-0193, Japan)

${ }^{7}$ 広島工業大学生体医工学科, =731-5193 広島県広島市佐伯区三宅2-1-1 (Department of Clinical Engineering, Hiroshima Institute of Technology, 2-1-1 Miyake, Saeki-ku, Hiroshima-city, Hiroshima 731-5193, Japan)
\end{abstract}

Received: February 29, 2016 / Accepted: June 15, 2016

\begin{abstract}
The purpose of the present study was to indicate the relationship between health-related quality of life (HRQOL) measures, the daily rhythm of oral temperature (OT), and lifestyle. Five-hundred young men volunteered to participate in this study. Their OT, measured using a digital thermometer, was recorded every $2 \mathrm{~h}$ from the time they woke up to the time they went to sleep for 1 week. The daily rhythm of OT was calculated as a quadratic function using the 1-week data. The HRQOL was measured using the Short-Form 36-Item Health Survey version 2 (SF-36v2). The participants were divided into 3 groups: a high-value group (HG) with $\geq 55$ points of each summary score and each subscale score, a middle-value group (MG) with score > 45 and $<55$ points, and a low-value group (LG) with score $\leq 45$ points. Lifestyle was assessed in terms of eating habits, sleeping and exercise, and the presence of unidentified complaints. At the mental component summary, the OT at the time of waking up and the peak OT in the HG were significantly higher than those in the LG. At the physical and mental component summary, lifestyle in the HG was more favorable. These data suggest that the daily rhythms of OT may reflect the mental health status of an individual. The entraining factors in circadian variation might play a role in improving mental health and reducing unidentified complaints. In conclusion, there appears to be an association between mental health status, lifestyle, and daily rhythms of OT.
\end{abstract}

Jpn J Phys Fitness Sports Med, 65(4): 431-440 (2016)

Keywords : health-related quality of life, daily rhythm, lifestyle, unidentified complaints, oral temperature

緒言

ヒトは 1 日を周期として変動する概日リズムを有す る。概日リズムは生体内の様々な生理現象に関与し, 恒 常性維持に重要な役割を担う1)。体温のリズムは最も基 本的な概日リズムの 1 つである ${ }^{1)}$. 起床前 (4-6 時) の
体温は最も低く, その後上昇し 16-18時頃ピークを迎え, 夜再び下降する ${ }^{2)}$. 体温は, 心拍数, 血圧, 心臓自律神経 系活動などの指標と関連し，概日リズムに対応した生理 応答を示すことが明らかになっている年21). ヒトの自律 神経系は, 夜間睡眠中の副交感神経系が優位な状態から 起床後に交感神経系にスイッチングし，日中は交感神経 
系が艺進し，副交感神経系は抑制される

先行研究は概日リズムが 24 時間より長い周期を有す る ${ }^{6)}$ が，同調因子によって 24 時間周期に調整されること を報告している. 最も強い同調因子は, 光である7). 一方

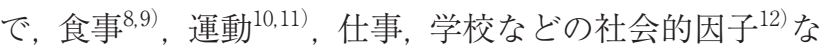
どの非光因子も存在する。先行研究は, 同調因子が体温 などの概日リズムの振幅, 位相などに影響し, 同調因子 の強弱が明確な概日リズムの獲得に寄与する可能性を指 摘している ${ }^{13,14)}$ 。また, 同調因子は, 乱れた概日リズムの 修復にも寄与することが指摘されている ${ }^{15)}$. 中高齢者に おいて，夜間睡眠中の体温低下幅が小さく，体温の最高 值と最低值の差も低值を示すことが報告されている ${ }^{16)}$. これらの先行研究は，概日リズムが光暴露，生活習慣， 加齢などの影響を受け, 位相あるいは振幅を変化させる ことを示唆している。つまり，体温の概日リズムの形成 ならびに修復に午前中の光暴露および朝食摂取が関与す る可能性がある。また, 加齢に伴い概日リズムは振幅を 低下させるものと考えられる。これらの知見は，基本的 な生活習慣の確立が良好な概日リズムに寄与することを 示唆している。概日リズムは各個人の習慣的な生活習慣 を反映するものと考えられることから，各個人が自己の 概日リズムを把握することは習慣的な生活習慣の乱れに 伴う不定愁訴などの把握に有益である可能性がある.

概日リズムは同調因子が存在しない環境下ではフリー ランを惹起し, 生理応答は 24 時間周期から乱れが生じ るとされている ${ }^{6)}$ 。概日リズムの乱れは，概日リズム睡 眠障害 ${ }^{17)}$, 不定愁訴発現 ${ }^{18)}$, 生活習慣病罹患 ${ }^{19-21)}$, うつ 病罹患 ${ }^{22)}$ などと関連することから, 日常における生活の 質（Quality of life; QOL）にも影響を与える可能性があ る。QOLは,「生きがい」,「満足度」,「居住環境」,「経 済状態」，「ソーシャルサポート」などを含め多種多様な 定義が存在する ${ }^{23)}$ 。健康関連 QOL (Heath-related QOL; HRQOL）は，「身体機能」，「精神機能」，「社会生活・役 割機能」の基本的要素から構成されている. HRQOLを 包括的に評価する尺度の 1 つに36-Item Short-Form Health Survey（SF-36）がある. 日本語版のSF-36は, 我が国の文化的側面を配慮された形の表現に修正され， その信頼性, 妥当性が認められている24,25).SF-36にお ける HRQOLは「身体的側面」および「精神的側面」の 2 つの因子によって規定され，8つの下位尺度（「身体機 能」, 「日常役割機能 (身体)」, 「体の痛み」, 「全体的健 康感」,「活力」, 「社会生活機能」,「日常役割機能 (精神) 」, 「心の健康」) で構成される，また，その下位尺度に基づき， 「身体的側面 QOL サマリースコア」,「精神的側面 QOL サマリースコア」および「役割／社会的側面QOLサマ リースコア」を評価することができる。先行研究におい ては，SF-36を用いて，アトピー性皮膚炎患者における QOL 評価 ${ }^{26)}$ ，透析患者における QOL 評価 ${ }^{27)}$ な゙の特定
の患者のQOL評価のみならず，女子大学生における食 事パターンとQOLの評価 ${ }^{28)}$ など健常者における QOL評 価にも用いられている。

大学生は一般的に生活習慣の質が低く, 精神的健康度 も低いことが報告されている ${ }^{29)}$ ，特に，男子学生は，女 子学生に比較して, 生活習慣の悪化が顕著であること ${ }^{29)}$, 健康教育介入の効果が薄いことなどが指摘されている. これらの先行研究から, 男子大学生は生活習慣が悪化 し, 精神的健康度も低いことが特徴であるものと考えら れる。加龃に伴う活動性や社会性の低下, 感覚器受容性 の低下による同調因子が減弱化することから ${ }^{30)}$, 大学時 代における生活習慣の乱れによる概日リズムの徳化は加 齢に伴う概日リズムの衰退を加速させることが推測され る。これらのことから, 男子大学生を対象に生活習慣お よび健康度と体温の日内変動特性の関連性を明らかにす ることは意義深いものと考えられる.

以上の先行研究の知見に基づき，良好な生活習慣者は 体温の概日リズムに優れ，健康度のスコアが高いものと 仮説立てを行った。本研究は研究仮説を検証するため, HRQOLのサマリースコア・下位尺度の得点で群分けし, 舌下温の日内変動特性, 基本的な生活習慣との関連性を 検討することを目的とした。舌下温の日内変動特性とし て, 起床 · 就寝時舌下温, 舌下温の最高值, 起床時の舌 下温と最高值の差，就寝時の舌下温と最高值の差，最高 值の出現時刻，起床時から最高值の位相時間，最高值か ら就寝時の位相時間を評価した。

\section{方法}

対象者 対象者は健康な男子大学生 500名（年歯令 19-22 歳）であった，対象者には，ヘルシンキ宣言および広島 工業大学研究倫理規程の趣旨に沿い, 研究の目的, 方法, 期待される効果, 不利益がないこと, 個人情報の保護に ついて説明を行い, 研究参加者から同意を得た。本研究 は広島工業大学生命学部研究倫理審査委員会の承認を得 た後に実施した（生15-003）。

測定項目 測定項目は，舌下温，起床 ·就寝時刻，生活 習慣に関する調査および健康関連尺度指標とした。対象 者は，電子体温計（オムロン社； $\mathrm{MC}-672 \mathrm{~L}, 0.01^{\circ} \mathrm{C}$ 単位) を用いて，起床後から就寝まで 2 時間毎に 1 週間舌下温 の実測值を測定した。得られた 1 週間の舌下温の実測值 から最小二乗法（X軸；測定時刻, $\mathrm{Y}$ 軸 ; 舌下温）を用 いて近似式（二次回帰曲線）を求めた。得られた近似式 から起床時および就寝時の舌下温, 舌下温の最高值，起 床時と最高值の差, 就寝時と最高值の差, 最高值の出現 時刻，起床時から最高值の位相時間，最高值から就寝時 の位相時間を求め, 舌下温の日内変動特性と定義した (Fig. 1). 起床・就寝時刻調査は，対象者に舌下温の測 
定を行った 1 週間に起床・就寝時刻を申告させ，実施し た。対象者には事前に説明会を開催し，「対象者には普 段通りの生活を送ること」，「舌下温の実測值（5分間の 測定）を測定すること」，「舌下温の測定は座位姿勢で行 うこと」，「起床後から就寝まで 2 時間毎に測定すること (例えば午前 8 時の測定なら, 午前 7-9 時の間に測定す ること)」,「食事直後, 部活動や体育の授業などの激し い運動直後, 帰宅直後, 入浴直後の測定は避けること (可 能な範囲でそれらの活動の前に測定すること)」を説明 した。舌下温の測定方法については取扱い説明書を配布 し，検者の前で対象者が実際に測定を行い，正しい測定 方法での測定を確認した，調査終了の際は, 対象者に「実 測值を測定したこと」，「体調不良等の生活に著しい変化 がなかったこと」,「虚偽の記載がないこと」を口頭で確 認した。

生活習慣に関する質問紙調査は, 食事回数, 朝食摂取, 睡眠時間，運動，アルバイト実施時間帯の実施状況，不 定愁訴発現に関する項目とした (自記式). 対象者は舌 下温の測定終了日に生活習慣に関する質問紙調査の回答 を行った。

HRQOL尺度指標は SF-36v2 日本語版（認定 NPO 法人 健康医療評価研究機構）を用いた（自記式）。対象者は
舌下温の測定開始日にSF-36v2 日本語版の回答を行っ た。得られた資料の分析には, SF-36v2 日本語版スコア リングプログラムを用いた（iHope International株式会 社)。 HRQOLのサマリースコア（身体的側面 QOL, 精神 的側面 QOL, 役割 / 社会的側面 QOL) および下位尺度 (身 体機能, 日常役割機能 (身体), 体の痛み, 全体的健康感, 活力, 社会生活機能, 日常役割機能 (精神), 心の健康) の 得点を求めた。各サマリースコアおよび各下位尺度の分 析は，国民標準值で補正し，評価した。なお，SF-36v2 日本語版は認定 NPO 法人健康医療評価研究機構から使 用許諾を得た。

分析方法 舌下温の測定回数が $75 \%$ 未満の者, 最小二乗 法で近似させた際の相関係数が mean $\pm 2 \mathrm{SD}$ 範囲外の者, 起床時, 最高值, 睡眠時の舌下温, 舌下温の最高值の值 が mean $\pm 2 \mathrm{SD}$ の範囲外の者は解析対象者から除外した。 本研究の解析対象者は, 422 名であった。

HRQOLのサマリースコアおよび各下位尺度の 55 点以 上（国民標準值 50 点の $10 \%$ 以上）を高值群，55点未満 から 45 点以上を中值群，45点未満（国民標準值 50 点の 10\%未満）を低值群とした。各群における舌下温の日内 変動特性, 生活習慣を評価した。

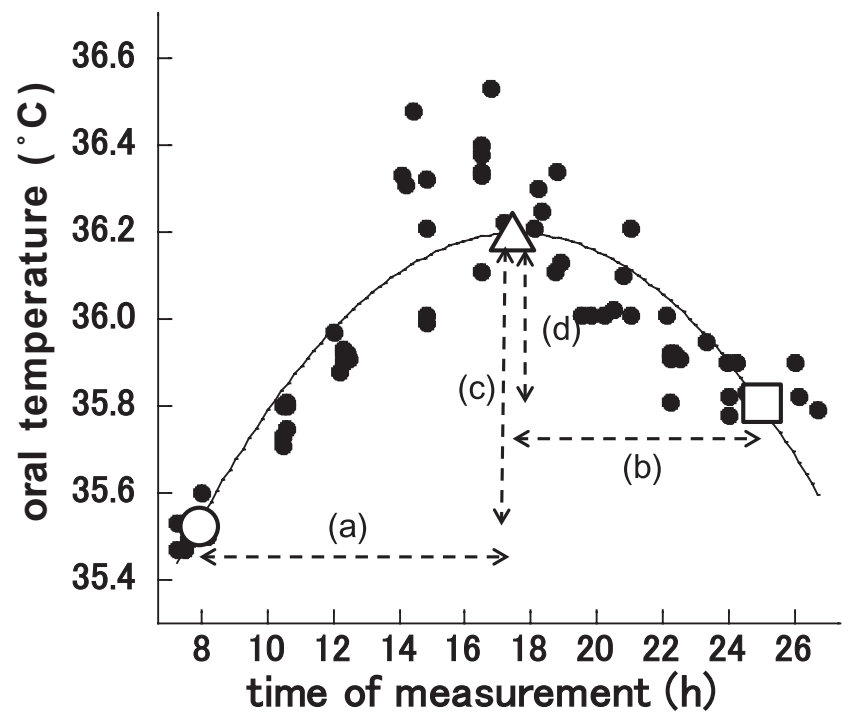

oral temperature at the time of waking up (O)

peak oral temperature $(\Delta)$

oral temperature at the time of going to bed $(\square)$

time of peak oral temperature $(\Delta)$

differences in oral temperature between peak value and the value at the time of waking up (c) differences in oral temperature between peak value and the value at the time of going to bed (d) differences in time between peak and the waking up (a) differences in time between peak and the going to bed (b) 
統計処理 測定值は, 平均值 \pm 標準偏差 $($ mean $\pm \mathrm{SD})$ で示した，各サマリースコアおよび各下位尺度の各群に 扔ける日内変動特性の正規性を事前に検定した。群間の 比較には一元配置分散分析を用い検定した，有意な差が 観察された場合は, Bonferroni/Dunnを用い事後検定を 行った。いずれの場合も危険率 $5 \%$ 未満 $(\mathrm{p}<0.05)$ を有 意な差とし， $5 \%$ 以上 $10 \%$ 未満を有意でないものの傾向 が観察されたと定義した。

\section{結 果}

本研究で得られた舌下温の日内変動特性は, 起床時舌 下温； $36.07 \pm 0.41^{\circ} \mathrm{C}$, 舌下温の最高值； $36.68 \pm 0.34^{\circ} \mathrm{C}$, 就寝時舌下温; $36.27 \pm 0.44^{\circ} \mathrm{C}$, 起床時と最高值の差 ; 0.61 $\pm 0.33^{\circ} \mathrm{C}$, 就寝時と最高值の差; $0.44 \pm 0.33^{\circ} \mathrm{C}$, 最高值の 出現時刻 ; $17.6 \pm 2.0$ 時, 起床時から最高值の位相時間 ; $9.4 \pm 2.0$ 時掞よび最高值から就寝時の位相時間； $7.3 \pm 2.0$ 時であった. 本研究の対象者の起床㧍よび就寝時刻は 8.1 \pm 1.1 時および $24.8 \pm 1.2$ 時であり, 睡眠時間は $7.4 \pm 1.3$ 時 間であった。本研究で得られた $\mathrm{SF}-36 \mathrm{v} 2$ のサマリース コアをTable 1-aに示した，各サマリースコアは，身体 的側面 QOLサマリースコア；55.6 06.8 点，精神的側面 QOLサマリースコア； $48.5 \pm 9.4$ 点, 役割/社会的㑯面 QOLサマリースコア；46.1 10.1 点であった。本研究で 得られた SF-36v2の各下位尺度の得点を示した。各下位 尺度の得点は, 身体機能; $53.9 \pm 5.9$ 点, 日常役割機能 (身 体）; $48.3 \pm 9.1$ 点, 体の痛み; $52.6 \pm 9.4$ 点, 全体的健康感; $50.6 \pm 9.4$ 点, 活力; $47.3 \pm 9.6$ 点, 社会生活機能; $49.2 \pm 9.8$ 点, 日常役割機能 (精神)； $47.2 \pm 9.8$ 点, 心の健康； 47.2 土9.3点であった（Table 1-b).

Table 2に各サマリースコア（身体的側面 QOL, 精神 的側面 QOL および役割／社会的側面 QOL）の高值群, 中値群および低值群における生活習慣者の割合を示し た。身体的側面 QOLサマリースコアの高值群および中 值群は，低值群に比較して，1日3食摂取する者抢よび 運動習慣者の割合が大きく, 睡眠時間が 6 時間未満の者, 運動非習慣者および不定愁訴を訴える者の割合が小さ かった，精神的側面 QOLサマリースコアの高值群は, 中 值群および低值群に比較して，1日 3 食摂取する者抢よ び運動習慣者の割合が大きく，運動非習慣者の割合が小 さかった，朝食を毎日摂取する者の割合は，高值群，中
值群，低值群の順に低値を示した，一方，不定愁訴を訴 える者の割合は，高値群，中値群，低值群の順に高值を 示した。役割／社会的側面 QOLサマリースコアの中值 群は, 高值群および低值群に比較して, 睡眠時間が 6 時 間未満の者，運動非習慣者㧍よび不定愁訴を訴える者の 割合が小さかった。

各サマリースコア（a．身体的側面 QOL，b．精神的側 面 QOL，c . 役割／社会的側面 QOL）の高值群，中值群 および低值群の舌下温の日内変動特性を Table 3 に示し た。精神的側面QOLサマリースコアに扔ける起床時舌 下温, 舌下温の最高值，起床時と最高值の差に有意な差 が観察された。高值群の起床時の舌下温は，低值群に比 較して，有意な高值を示した。高值群および中值群の舌 下温の最高値は, 低值群に比較して, 有意な高値を示し た. 中値群の起床時と最高值の差は, 低値群に比較して, 有意な高值を示した，就寝時舌下温，就寝時と最高值の 差，最高值の出現時刻，起床時から最高值の位相時間お よび最高値から就寝時の位相時間は，群間に有意な差は 観察されなかった。身体的側面 QOL お方よび役割／社会 的側面 QOLに扔ける舌下温の日内变動特性に群間に有 意な差は観察されなかった。

Table 4 に各下位尺度（a．身体機能，b.日常役割機能 (身体)，c．体の痛み， d，全体的健康感，e．活力， f，社 会生活機能, g. 日常役割機能 (精神), h. 心の健康) の

Table 1. The summary score (a) and subscale score (b) at health-related quality of life

\begin{tabular}{cc} 
a. summary score & \\
\hline \hline & mean $\pm \mathrm{SD}$ \\
\hline \hline physical component summary (points) & $55.6 \pm 6.8$ \\
mental component summary (points) & $48.5 \pm 9.4$ \\
role/social component summary (points) & $46.1 \pm 10.1$ \\
\hline
\end{tabular}

\section{b. subscale score}

\begin{tabular}{cc}
\hline & mean \pm SD \\
\hline \hline physical functioning (points) & $53.9 \pm 5.9$ \\
role physical (points) & $48.3 \pm 9.1$ \\
bodily pain (points) & $52.6 \pm 9.4$ \\
general health (points) & $50.6 \pm 9.4$ \\
vitality (points) & $47.3 \pm 9.6$ \\
social functioning (points) & $49.2 \pm 9.8$ \\
role emotional (points) & $47.2 \pm 9.8$ \\
mental health (points) & $47.2 \pm 9.3$ \\
\hline
\end{tabular}

Table 2. The lifestyle between high-value group and low-value group at each summary score

\begin{tabular}{|c|c|c|c|c|c|c|c|c|c|}
\hline & \multicolumn{3}{|c|}{ physical component summary } & \multicolumn{3}{|c|}{ mental component summary } & \multicolumn{3}{|c|}{ role/social component summary } \\
\hline & high-value group & middle-value group & low-value group & high-value group & middle-value group & low-value group & high-value group & middle-value group & low-value group \\
\hline rate of having meals 3 times a day & 39.4 & 46.2 & 22.2 & 50.0 & 38.7 & 35.9 & 36.7 & 42.3 & 40.7 \\
\hline rate of having breakfast & 40.6 & 40.8 & 40.7 & 47.0 & 40.5 & 36.6 & 36.7 & 43.6 & 40.7 \\
\hline rate of sleeping for less than 6 hours & 39.4 & 26.1 & 50.0 & 29.6 & 23.3 & 51.7 & 37.8 & 25.5 & 44.6 \\
\hline rate of exercise habit & 34.7 & 30.8 & 22.2 & 42.0 & 28.8 & 26.1 & 35.6 & 41.0 & 29.9 \\
\hline rate of lack of exercise habit & 65.3 & 69.2 & 77.8 & 58.0 & 71.2 & 73.9 & 64.4 & 59.0 & 70.1 \\
\hline rate of unidentified complaints & 50.0 & 58.5 & 85.2 & 29.0 & 51.8 & 76.0 & 54.5 & 44.0 & 63.5 \\
\hline
\end{tabular}


Table 3. The daily rhythm of oral temperature between high-value group and low-value group at physical component (a), mental component (b), and role/social component (c)

\begin{tabular}{|c|c|c|c|c|c|}
\hline & high-value group & middle-value group & low-value group & F-value & $\mathrm{p}$-value \\
\hline sample number $(n)$ & 258 & 135 & 29 & & \\
\hline oral temperature at the time of waking up $\left({ }^{\circ} \mathrm{C}\right)$ & $36.09 \pm 0.38$ & $36.08 \pm 0.36$ & $36.13 \pm 0.40$ & 0.217 & 0.805 \\
\hline peak oral temperature $\left({ }^{\circ} \mathrm{C}\right)$ & $36.72 \pm 0.36$ & $36.71 \pm 0.31$ & $36.77 \pm 0.31$ & 0.346 & 0.708 \\
\hline oral temperature at the time of going to bed $\left({ }^{\circ} \mathrm{C}\right)$ & $36.27 \pm 0.43$ & $36.29 \pm 0.43$ & $36.37 \pm 0.39$ & 0.554 & 0.575 \\
\hline differences in oral temperature between peak value and the value at the time of waking up $\left({ }^{\circ} \mathrm{C}\right)$ & $0.63 \pm 0.30$ & $0.64 \pm 0.31$ & $0.63 \pm 0.31$ & 0.065 & 0.937 \\
\hline differences in oral temperature between peak value and the value at the time of going to bed $\left({ }^{\circ} \mathrm{C}\right)$ & $0.45 \pm 0.32$ & $0.46 \pm 0.34$ & $0.42 \pm 0.30$ & 0.115 & 0.892 \\
\hline time of peak oral temperature $(h)$ & $17.1 \pm 1.6$ & $17.5 \pm 1.9$ & $17.5 \pm 1.5$ & 1.750 & 0.175 \\
\hline differences in time between peak and the waking up ( $h$ ) & $9.1 \pm 1.5$ & $9.4 \pm 1.9$ & $9.3 \pm 1.7$ & 1.104 & 0.333 \\
\hline differences in time between peak and the going to bed (h) & $7.5 \pm 1.9$ & $7.3 \pm 2.1$ & $7.5 \pm 1.4$ & 0.389 & 0.678 \\
\hline
\end{tabular}

b. mental component summary

\begin{tabular}{|c|c|c|c|c|c|}
\hline & high-value group & middle-value group & low-value group & F-value & $p$-value \\
\hline sample number $(n)$ & 102 & 174 & 146 & & \\
\hline oral temperature at the time of waking up $\left({ }^{\circ} \mathrm{C}\right)$ & $36.17 \pm 0.38$ & $36.08 \pm 0.36$ & $36.05 \pm 0.36$ & 3.153 & 0.044 \\
\hline peak oral temperature $\left({ }^{\circ} \mathrm{C}\right)$ & $36.76 \pm 0.35$ & $36.75 \pm 0.34$ & $36.64 \pm 0.32$ & 5.434 & 0.005 \\
\hline oral temperature at the time of going to bed $\left({ }^{\circ} \mathrm{C}\right)$ & $36.20 \pm 0.40$ & $36.27 \pm 0.44$ & $36.26 \pm 0.41$ & 0.504 & 0.604 \\
\hline differences in oral temperature between peak value and the value at the time of waking up $\left({ }^{\circ} \mathrm{C}\right)$ & $0.61 \pm 0.25$ & $0.69 \pm 0.32$ & $0.59 \pm 0.30$ & 4.343 & 0.014 \\
\hline differences in oral temperature between peak value and the value at the time of going to bed $\left({ }^{\circ} \mathrm{C}\right)$ & $0.40 \pm 0.30$ & $0.49 \pm 0.37$ & $0.39 \pm 0.27$ & 1.703 & 0.184 \\
\hline time of peak oral temperature $(h)$ & $17.1 \pm 1.5$ & $17.5 \pm 2.0$ & $17.5 \pm 1.5$ & 1.863 & 0.157 \\
\hline differences in time between peak and the waking up (h) & $9.0 \pm 1.6$ & $9.4 \pm 1.9$ & $9.4 \pm 1.5$ & 2.088 & 0.125 \\
\hline differences in time between peak and the going to bed (h) & $7.3 \pm 2.2$ & $7.3 \pm 1.9$ & $7.3 \pm 2.1$ & 0.041 & 0.959 \\
\hline \multicolumn{6}{|l|}{ b. mental component summary (post-hoc test, p-value) } \\
\hline & high vs middle & high vs low & middle vs low & & \\
\hline oral temperature at the time of waking up $\left({ }^{\circ} \mathrm{C}\right)$ & 0.053 & 0.015 & 0.517 & & \\
\hline peak oral temperature $\left({ }^{\circ} \mathrm{C}\right)$ & 0.852 & 0.007 & 0.004 & & \\
\hline differences in oral temperature between peak value and the value at the time of waking up $\left({ }^{\circ} \mathrm{C}\right)$ & 0.070 & 0.462 & 0.004 & & \\
\hline \multicolumn{6}{|l|}{ c. role/social component summary } \\
\hline & high-value group & middle-value group & low-value group & F-value & $\mathrm{p}$-value \\
\hline sample number $(n)$ & 93 & 160 & 169 & & \\
\hline oral temperature at the time of waking up $\left({ }^{\circ} \mathrm{C}\right)$ & $36.13 \pm 0.40$ & $36.09 \pm 0.39$ & $36.02 \pm 0.37$ & 0.841 & 0.432 \\
\hline peak oral temperature $\left({ }^{\circ} \mathrm{C}\right)$ & $36.75 \pm 0.36$ & $36.71 \pm 0.35$ & $36.71 \pm 0.33$ & 0.486 & 0.616 \\
\hline oral temperature at the time of going to bed $\left({ }^{\circ} \mathrm{C}\right)$ & $36.34 \pm 0.46$ & $36.25 \pm 0.39$ & $36.27 \pm 0.47$ & 0.829 & 0.438 \\
\hline differences in oral temperature between peak value and the value at the time of waking up $\left({ }^{\circ} \mathrm{C}\right)$ & $0.62 \pm 0.35$ & $0.63 \pm 0.30$ & $0.66 \pm 0.31$ & 0.480 & 0.619 \\
\hline differences in oral temperature between peak value and the value at the time of going to bed $\left({ }^{\circ} \mathrm{C}\right)$ & $0.40 \pm 0.23$ & $0.48 \pm 0.33$ & $0.43 \pm 0.33$ & 1.449 & 0.236 \\
\hline time of peak oral temperature $(h)$ & $17.6 \pm 2.0$ & $17.2 \pm 1.8$ & $17.4 \pm 1.7$ & 1.334 & 0.265 \\
\hline differences in time between peak and the waking up $(h)$ & $9.5 \pm 1.9$ & $9.1 \pm 1.8$ & $9.3 \pm 1.7$ & 1.099 & 0.334 \\
\hline differences in time between peak and the going to bed ( $h$ ) & $7.4 \pm 1.9$ & $7.4 \pm 1.9$ & $7.3 \pm 2.1$ & 0.140 & 0.869 \\
\hline
\end{tabular}

高低で比較した舌下温の日内変動特性を示した。全体的 健康感に抢ける起床時と最高值の差に有意な差が観察さ れた。高值群および中值群の起床時と最高值の差は, 低 值群に比較して, 有意な高值を示した。舌下温の最高値 および起床時から最高值の位相時間は有意な差ではない ものの傾向が観察された. 日常役割機能 (精神) において, 最高值の出現時刻掞よび起床時から最高値の位相時間に 有意な差が観察された，高值群および中值群の最高值の 出現時刻は, 低值群に比較して, 有意な早い時間带であっ た。高值群抢よび中值群の起床時から最高值の位相時間 は，低值群に比較して，有意な低值を示した。心の健康 における舌下温の最高值に有意な差が観察された。高値 群の舌下温の最高值は, 中值群抒よび低值群に比較して, 有意な高値を示した，起床時の舌下温㧍よび最高值の出
現時刻は有意な差ではないものの傾向が観察された，全 体的健康感, 日常役割機能 (精神), 心の健康の他の舌下 温の日内変動特性に打ける群間の比較に有意な差は観察 されなかった。また，身体機能，日常役割機能（身体）, 体の痛み, 活力, 社会生活機能における舌下温の日内变 動特性の群間の比較に有意な差は観察されなかった。

\section{考察}

本研究は, 男子大学生を対象に健康関連 QOL と舌下 温の日内変動特性, 生活習慣との関連性を明らかにした。 精神的健康度の高い者は, 起床時の舌下温拉よび舌下温 の最高值が高く, 起床時から最高值の位相時間が短いこ とが明らかになった。また，精神的健康度の高い者は, 良好な生活習慣を有し, 不定愁訴有訴率が低值であった。 
Table 4. The daily rhythm of oral temperature between high-value group and low-value group at each subscale score physical functioning (a), role physical (b), bodily pain (c), general health (d), vitality (e), social functioning (f), role emotional (g), mental health (h)

\begin{tabular}{|c|c|c|c|c|c|}
\hline & high-value group & middle-value group & low-value group & F-value & $\mathrm{p}$-value \\
\hline sample number $(n)$ & 219 & 169 & 34 & & \\
\hline oral temperature at the time of waking up $\left({ }^{\circ} \mathrm{C}\right)$ & $36.08 \pm 0.36$ & $36.10 \pm 0.39$ & $36.06 \pm 0.40$ & 0.112 & 0.894 \\
\hline peak oral temperature $\left({ }^{\circ} \mathrm{C}\right)$ & $36.72 \pm 0.34$ & $36.71 \pm 0.35$ & $36.73 \pm 0.26$ & 0.057 & 0.944 \\
\hline oral temperature at the time of going to bed $\left({ }^{\circ} \mathrm{C}\right)$ & $36.29 \pm 0.39$ & $36.26 \pm 0.47$ & $36.34 \pm 0.40$ & 0.454 & 0.636 \\
\hline differences in oral temperature between peak value and the value at the time of waking up $\left({ }^{\circ} \mathrm{C}\right)$ & $0.64 \pm 0.31$ & $0.62 \pm 0.31$ & $0.68 \pm 0.31$ & 0.497 & 0.609 \\
\hline differences in oral temperature between peak value and the value at the time of going to bed $\left({ }^{\circ} \mathrm{C}\right)$ & $0.44 \pm 0.30$ & $0.47 \pm 0.36$ & $0.43 \pm 0.35$ & 0.454 & 0.636 \\
\hline time of peak oral temperature $(h)$ & $17.4 \pm 1.8$ & $17.4 \pm 1.8$ & $17.9 \pm 2.3$ & 1.145 & 0.319 \\
\hline differences in time between peak and the waking up ( $h$ ) & $9.3 \pm 1.8$ & $9.3 \pm 1.8$ & $9.9 \pm 1.8$ & 1.871 & 0.155 \\
\hline differences in time between peak and the going to bed ( $h$ ) & $7.4 \pm 1.9$ & $7.4 \pm 2.0$ & $7.1 \pm 2.1$ & 0.303 & 0.739 \\
\hline
\end{tabular}

\section{b. role physical}

\begin{tabular}{|c|c|c|c|c|c|}
\hline & high-value group & middle-value group & low-value group & F-value & $\mathrm{p}$-value \\
\hline sample number ( $n$ ) & 196 & 87 & 139 & & \\
\hline oral temperature at the time of waking up $\left({ }^{\circ} \mathrm{C}\right)$ & $36.09 \pm 0.39$ & $36.11 \pm 0.41$ & $36.06 \pm 0.35$ & 0.485 & 0.616 \\
\hline peak oral temperature $\left({ }^{\circ} \mathrm{C}\right)$ & $36.73 \pm 0.36$ & $36.73 \pm 0.35$ & $36.70 \pm 0.31$ & 0.349 & 0.706 \\
\hline oral temperature at the time of going to bed $\left({ }^{\circ} \mathrm{C}\right)$ & $36.27 \pm 0.44$ & $36.29 \pm 0.42$ & $36.28 \pm 0.45$ & 0.029 & 0.971 \\
\hline differences in oral temperature between peak value and the value at the time of waking up $\left({ }^{\circ} \mathrm{C}\right)$ & $0.64 \pm 0.30$ & $0.63 \pm 0.29$ & $0.64 \pm 0.33$ & 0.064 & 0.938 \\
\hline differences in oral temperature between peak value and the value at the time of going to bed $\left({ }^{\circ} \mathrm{C}\right)$ & $0.47 \pm 0.32$ & $0.44 \pm 0.35$ & $0.44 \pm 0.35$ & 0.320 & 0.726 \\
\hline time of peak oral temperature $(h)$ & $17.3 \pm 1.9$ & $17.4 \pm 1.7$ & $17.5 \pm 2.0$ & 0.501 & 0.606 \\
\hline differences in time between peak and the waking up (h) & $9.2 \pm 1.9$ & $9.3 \pm 1.5$ & $9.4 \pm 2.1$ & 0.432 & 0.650 \\
\hline differences in time between peak and the going to bed (h) & $7.4 \pm 2.0$ & $7.4 \pm 1.8$ & $7.2 \pm 2.1$ & 0.231 & 0.794 \\
\hline
\end{tabular}

\begin{tabular}{|c|c|c|c|c|c|}
\hline & high-value group & middle-value group & low-value group & F-value & $p$-value \\
\hline sample number $(n)$ & 242 & 106 & 74 & & \\
\hline oral temperature at the time of waking up $\left({ }^{\circ} \mathrm{C}\right)$ & $36.09 \pm 0.36$ & $36.07 \pm 0.39$ & $36.08 \pm 0.38$ & 0.115 & 0.891 \\
\hline peak oral temperature $\left({ }^{\circ} \mathrm{C}\right)$ & $36.74 \pm 0.35$ & $36.69 \pm 0.33$ & $36.67 \pm 0.31$ & 1.697 & 0.185 \\
\hline oral temperature at the time of going to bed $\left({ }^{\circ} \mathrm{C}\right)$ & $36.30 \pm 0.40$ & $36.24 \pm 0.44$ & $36.28 \pm 0.47$ & 0.692 & 0.501 \\
\hline differences in oral temperature between peak value and the value at the time of waking up $\left({ }^{\circ} \mathrm{C}\right)$ & $0.65 \pm 0.30$ & $0.62 \pm 0.33$ & $0.60 \pm 0.29$ & 0.928 & 0.396 \\
\hline differences in oral temperature between peak value and the value at the time of going to bed $\left({ }^{\circ} \mathrm{C}\right)$ & $0.44 \pm 0.28$ & $0.47 \pm 0.33$ & $0.42 \pm 0.38$ & 0.490 & 0.613 \\
\hline time of peak oral temperature $(h)$ & $17.5 \pm 1.9$ & $17.3 \pm 1.9$ & $17.6 \pm 2.1$ & 0.302 & 0.739 \\
\hline differences in time between peak and the waking up $(h)$ & $9.4 \pm 1.9$ & $9.3 \pm 1.7$ & $9.2 \pm 2.1$ & 0.508 & 0.602 \\
\hline differences in time between peak and the going to bed (h) & $7.4 \pm 1.7$ & $7.4 \pm 2.2$ & $7.0 \pm 2.3$ & 1.078 & 0.342 \\
\hline
\end{tabular}

\begin{tabular}{|c|c|c|c|c|c|}
\hline & high-value group & middle-value group & low-value group & $\mathrm{F}$-value & $\mathrm{p}$-value \\
\hline sample number $(n)$ & 154 & 136 & 132 & & \\
\hline oral temperature at the time of waking up $\left({ }^{\circ} \mathrm{C}\right)$ & $36.10 \pm 0.40$ & $36.05 \pm 0.37$ & $36.11 \pm 0.35$ & 0.910 & 0.404 \\
\hline peak oral temperature $\left({ }^{\circ} \mathrm{C}\right)$ & $36.76 \pm 0.34$ & $36.72 \pm 0.35$ & $36.66 \pm 0.32$ & 2.931 & 0.054 \\
\hline oral temperature at the time of going to bed $\left({ }^{\circ} \mathrm{C}\right)$ & $36.29 \pm 0.42$ & $36.29 \pm 0.43$ & $36.26 \pm 0.42$ & 0.213 & 0.808 \\
\hline differences in oral temperature between peak value and the value at the time of waking up $\left({ }^{\circ} \mathrm{C}\right)$ & $0.66 \pm 0.31$ & $0.68 \pm 0.33$ & $0.56 \pm 0.27$ & 5.721 & 0.004 \\
\hline differences in oral temperature between peak value and the value at the time of going to bed $\left({ }^{\circ} \mathrm{C}\right)$ & $0.50 \pm 0.37$ & $0.44 \pm 0.31$ & $0.40 \pm 0.27$ & 2.518 & 0.082 \\
\hline time of peak oral temperature $(h)$ & $17.2 \pm 1.7$ & $17.5 \pm 1.7$ & $17.6 \pm 1.9$ & 1.799 & 0.167 \\
\hline differences in time between peak and the waking up (h) & $9.0 \pm 1.7$ & $9.5 \pm 1.8$ & $9.5 \pm 1.8$ & 2.931 & 0.055 \\
\hline differences in time between peak and the going to bed ( $h$ ) & $7.5 \pm 1.9$ & $7.3 \pm 1.7$ & $7.3 \pm 2.2$ & 0.199 & 0.820 \\
\hline
\end{tabular}

\begin{tabular}{ccc} 
high vs middle & high vs low & middle vs low \\
\hline 0.594 & 0.007 & 0.002 \\
\hline
\end{tabular}




\begin{tabular}{|c|c|c|c|c|c|}
\hline & high-value group & middle-value group & low-value group & F-value & $\mathrm{p}$-value \\
\hline sample number $(n)$ & 89 & 146 & 187 & & \\
\hline oral temperature at the time of waking up $\left({ }^{\circ} \mathrm{C}\right)$ & $36.10 \pm 0.39$ & $36.11 \pm 0.37$ & $36.06 \pm 0.38$ & 0.717 & 0.489 \\
\hline peak oral temperature $\left({ }^{\circ} \mathrm{C}\right)$ & $36.73 \pm 0.36$ & $36.73 \pm 0.32$ & $36.69 \pm 0.33$ & 1.010 & 0.365 \\
\hline oral temperature at the time of going to bed $\left({ }^{\circ} \mathrm{C}\right)$ & $36.24 \pm 0.40$ & $36.29 \pm 0.41$ & $36.30 \pm 0.45$ & 0.466 & 0.628 \\
\hline differences in oral temperature between peak value and the value at the time of waking up $\left({ }^{\circ} \mathrm{C}\right)$ & $0.66 \pm 0.29$ & $0.63 \pm 0.31$ & $0.63 \pm 0.31$ & 0.266 & 0.767 \\
\hline differences in oral temperature between peak value and the value at the time of going to bed $\left({ }^{\circ} \mathrm{C}\right)$ & $0.48 \pm 0.33$ & $0.46 \pm 0.32$ & $0.43 \pm 0.34$ & 0.481 & 0.619 \\
\hline time of peak oral temperature $(h)$ & $17.3 \pm 1.7$ & $17.3 \pm 1.8$ & $17.6 \pm 1.9$ & 1.249 & 0.288 \\
\hline differences in time between peak and the waking up $(h)$ & $9.1 \pm 1.8$ & $9.2 \pm 1.7$ & $9.4 \pm 1.8$ & 0.708 & 0.493 \\
\hline differences in time between peak and the going to bed ( $h$ ) & $7.4 \pm 1.9$ & $7.5 \pm 1.8$ & $7.2 \pm 2.1$ & 0.746 & 0.475 \\
\hline
\end{tabular}

\section{f. social functioning}

\begin{tabular}{|c|c|c|c|c|c|}
\hline & high-value group & middle-value group & low-value group & F-value & $\mathrm{p}$-value \\
\hline sample number $(n)$ & 214 & 50 & 158 & & \\
\hline oral temperature at the time of waking up $\left({ }^{\circ} \mathrm{C}\right)$ & $36.10 \pm 0.39$ & $36.06 \pm 0.37$ & $36.06 \pm 0.39$ & 0.590 & 0.555 \\
\hline peak oral temperature $\left({ }^{\circ} \mathrm{C}\right)$ & $36.75 \pm 0.35$ & $36.69 \pm 0.33$ & $36.69 \pm 0.33$ & 1.512 & 0.222 \\
\hline oral temperature at the time of going to bed $\left({ }^{\circ} \mathrm{C}\right)$ & $36.33 \pm 0.39$ & $36.23 \pm 0.47$ & $36.24 \pm 0.45$ & 1.915 & 0.149 \\
\hline differences in oral temperature between peak value and the value at the time of waking up $\left({ }^{\circ} \mathrm{C}\right)$ & $0.65 \pm 0.30$ & $0.64 \pm 0.33$ & $0.64 \pm 0.32$ & 0.080 & 0.923 \\
\hline differences in oral temperature between peak value and the value at the time of going to bed $\left({ }^{\circ} \mathrm{C}\right)$ & $0.43 \pm 0.29$ & $0.47 \pm 0.36$ & $0.44 \pm 0.32$ & 0.295 & 0.745 \\
\hline time of peak oral temperature $(h)$ & $17.4 \pm 1.7$ & $17.1 \pm 1.9$ & $17.4 \pm 2.0$ & 0.488 & 0.614 \\
\hline differences in time between peak and the waking up (h) & $9.3 \pm 1.7$ & $9.2 \pm 2.2$ & $9.2 \pm 1.8$ & 0.094 & 0.910 \\
\hline differences in time between peak and the going to bed $(h)$ & $7.3 \pm 1.8$ & $7.9 \pm 1.9$ & $7.3 \pm 2.2$ & 1.331 & 0.266 \\
\hline
\end{tabular}

g. role emotional

\begin{tabular}{|c|c|c|c|c|c|}
\hline & high-value group & middle-value group & low-value group & F-value & $p$-value \\
\hline sample number $(n)$ & 175 & 62 & 185 & & \\
\hline oral temperature at the time of waking up $\left({ }^{\circ} \mathrm{C}\right)$ & $36.10 \pm 0.40$ & $36.10 \pm 0.35$ & $36.08 \pm 0.35$ & 0.126 & 0.882 \\
\hline peak oral temperature $\left({ }^{\circ} \mathrm{C}\right)$ & $36.74 \pm 0.35$ & $36.72 \pm 0.34$ & $36.69 \pm 0.33$ & 0.889 & 0.412 \\
\hline oral temperature at the time of going to bed $\left({ }^{\circ} \mathrm{C}\right)$ & $36.31 \pm 0.40$ & $36.20 \pm 0.47$ & $36.27 \pm 0.46$ & 1.283 & 0.279 \\
\hline differences in oral temperature between peak value and the value at the time of waking up $\left({ }^{\circ} \mathrm{C}\right)$ & $0.65 \pm 0.33$ & $0.62 \pm 0.26$ & $0.63 \pm 0.30$ & 0.304 & 0.738 \\
\hline differences in oral temperature between peak value and the value at the time of going to bed $\left({ }^{\circ} \mathrm{C}\right)$ & $0.45 \pm 0.30$ & $0.53 \pm 0.41$ & $0.42 \pm 0.32$ & 2.018 & 0.135 \\
\hline time of peak oral temperature $(h)$ & $17.3 \pm 1.8$ & $16.9 \pm 1.8$ & $17.8 \pm 1.7$ & 5.193 & 0.006 \\
\hline differences in time between peak and the waking up (h) & $9.2 \pm 1.7$ & $9.0 \pm 1.7$ & $9.6 \pm 1.8$ & 3.833 & 0.022 \\
\hline differences in time between peak and the going to bed (h) & $7.4 \pm 1.9$ & $7.8 \pm 1.9$ & $7.2 \pm 2.1$ & 1.760 & 0.174 \\
\hline
\end{tabular}

g. role emotional (post-hoc test, p-value)

\begin{tabular}{rrrr} 
& high vs middle & high vs low & middle vs low \\
\hline \hline time of peak oral temperature $(h)$ & 0.205 & 0.021 & 0.004 \\
differences in time between peak and the waking up $(h)$ & 0.611 & 0.018 & 0.031 \\
\hline
\end{tabular}

h. mental health

\begin{tabular}{|c|c|c|c|c|c|}
\hline & high-value group & middle-value group & low-value group & F-value & $\mathrm{p}$-value \\
\hline sample number $(n)$ & 119 & 122 & 181 & & \\
\hline oral temperature at the time of waking up $\left({ }^{\circ} \mathrm{C}\right)$ & $36.15 \pm 0.39$ & $36.04 \pm 0.33$ & $36.09 \pm 0.38$ & 2.350 & 0.097 \\
\hline peak oral temperature $\left({ }^{\circ} \mathrm{C}\right)$ & $36.81 \pm 0.34$ & $36.67 \pm 0.34$ & $36.70 \pm 0.32$ & 5.717 & 0.004 \\
\hline oral temperature at the time of going to bed $\left({ }^{\circ} \mathrm{C}\right)$ & $36.34 \pm 0.42$ & $36.24 \pm 0.43$ & $36.27 \pm 0.42$ & 1.378 & 0.254 \\
\hline differences in oral temperature between peak value and the value at the time of waking up $\left({ }^{\circ} \mathrm{C}\right)$ & $0.65 \pm 0.30$ & $0.64 \pm 0.27$ & $0.61 \pm 0.33$ & 0.753 & 0.472 \\
\hline differences in oral temperature between peak value and the value at the time of going to bed $\left({ }^{\circ} \mathrm{C}\right)$ & $0.49 \pm 0.34$ & $0.44 \pm 0.32$ & $0.41 \pm 0.29$ & 2.221 & 0.111 \\
\hline time of peak oral temperature $(h)$ & $17.1 \pm 1.4$ & $17.4 \pm 1.9$ & $17.7 \pm 2.1$ & 2.769 & 0.064 \\
\hline differences in time between peak and the waking up ( $h$ ) & $9.1 \pm 1.6$ & $9.3 \pm 1.8$ & $9.5 \pm 2.1$ & 2.165 & 0.116 \\
\hline differences in time between peak and the going to bed (h) & $7.4 \pm 1.8$ & $7.2 \pm 1.9$ & $7.3 \pm 2.1$ & 0.230 & 0.794 \\
\hline
\end{tabular}

h. mental health (post-hoc test, p-value)

\begin{tabular}{ccccc}
\hline & high vs middle & high vs low & middle vs low \\
\hline \hline peak oral temperature $\left({ }^{\circ} \mathrm{C}\right)$ & 0.002 & 0.006 & 0.498 & \\
\hline
\end{tabular}


一方，身体的健康度の高い者は良好な生活習慣を有して いたが，低い者と比較して舌下温の日内変動特性に明確 な関連性は観察されなかった。 以上の知見は，舌下温の 日内変動特性と精神的健康度が関連することを示唆し, 研究仮説を支持するものである.

概日リズムに対応した生理応答に関する先行研究は, 24 時間周期で変化する体温などの生理指標をコサイナー 法によって近似させ，近似式から振幅，位相などを算出 し, 関連性を評価している ${ }^{31}$ 。一方, 本研究は, 覚醒時 の舌下温の日内変動特性に着目した。つまり, 夜間睡眠 中の測定を行わず，体温の日内変動特性を評価した。 ま た，測定間隔を 2 時間毎としたことから，日内変動特性 の妥当性を高めるため 1 週間分のデー夕を分析対象にし た。 さらに, 舌下温の日内変動の個人差が大きいことか ら，500名を対象に評価した。本研究は夜間睡眠中の舌 下温の測定を行わないことから, 舌下温の最低值（午前 4-6 時 $\left.{ }^{2)}\right)$ は不明であるが起床時抢よび就寝時の舌下温 を算出し, 起床時, 就寝時と最高值の差を舌下温の振幅 として評価した。舌下温の位相は, 起床時刻, 就寝時刻 と最高值の時間的な差で評価した。本研究の起床時の舌 下温と舌下温の最高值の差は, 先行研究に扔ける概日リ ズムの振幅と比較すると低值である。つまり, 先行研究 の振幅と本研究の起床時と最高值の差は得られるデー夕 は異なるが, 同様の指標として, 評価できるものと考え られる。

本研究における SF-36v2の各サマリースコアは, 対象 者の集団特性として, 身体的側面 QOLが高く, 精神的お よび役割／社会的側面QOLは低い值を示した。この傾 向は, 我が国の大学生の精神的健康度の低下を指摘した 先行研究と同様である ${ }^{22,28,29)}$.

本研究においては，対象者に対して舌下温の測定期間 中は普段通りに生活を送るように指示した。 しかしなが ら, 測定期間中以外の生活習慣を把握していないことか ら，測定期間中の生活習慣が普段通りの生活習慣である か否かは不明である。つまり，測定を実施することによっ て, 対象者が規則正しい生活を送った可能性を否定する ことはできない。この点は本研究の限界であるものと考 える. SF-36v2の回答は舌下温の測定開始日に実施し, 生活習慣に関する調査は舌下温の測定最終日に回答を得 た. SF-36v2は1ヶ月間の振り返りを対象にし, 生活習 慣は舌下温の測定を行った 1 週間が対象となっている. それぞれの質問紙調査の対象期間は異なることから, 回 答日の違いによる影響は小さいものと考える。学生の 生活習慣は, 住居形態, 喫煙習慣, 通学方法, 経済状態, 信条など様々な要因の影響を受けることが推測される. しかしながら, 本研究に扔いてはこれらの要因を評価し ていないことから，これらの要因が調査デー夕に及ぼす 影響度は不明である。このことも本研究の限界点である。
概日リズムは 25 時間周期であることから食事, 運動, 学校などの社会的因子に同調することで，24時間周期に 修正される，概日リズムは，生体の恒常性を維持するた め, 様々な生理機能を担う ${ }^{11}$ 。光, 朝食摂取などの同調 因子が存在しない場合は，概日リズムはフリーランを惹 起し，生活リズムとの乘離が生じる，概日リズムの乱れ は, 睡眠障害 ${ }^{17)}$, 不定愁訴発現 ${ }^{18)}$ など関連し, 長期間の 乱れは精神疾患 ${ }^{22)}$ や生活習慣病 ${ }^{19-21)}$ を引き起こす。この ことから，精神面だけでなく，身体面の健康の維持・管 理を目的に，各個人が概日リズムを把握することは意義 深いものと考えられる。しかしながら, コサイナー法 ${ }^{31)}$, メラトニン分泌開始時刻 ${ }^{32)}$ などのこれまでの概日リズム の評価方法は, 夜間睡眠中の測定が必要なこと, 高価な 測定装置が必要なことなどの理由から一般に普及してい ないものと考える。これらの背景から，本研究は 1 週間 分の起床後から就寝まで 2 時間毎の舌下温の測定値か ら，体温の日内変動特性の評価を行った。この手法を用 いた概日リズムの評価は，これまでの方法と比較して， 安価に評価できることから，多くの対象者に応用できる ものと考えらえる.

本研究の対象者は男子大学生であった。一般的に, 男 子学生は, 女子学生と比較して, 学生生活における生活 習慣の悪化が顕著である ${ }^{29)}$ ，本研究では，生活習慣に関 する質問紙調査の結果より, 起床, 就寝時刻, 始業時間, 朝食摂取の有無, 運動習慣の有無, 深夜のアルバイトな ど様々な生活習慣のスタイルが男子学生には存在するこ とが示された。 また, 本研究で得られた起床・就寝時刻 および舌下温, 舌下温の最高值, 最高值が出現した時刻, 起床・就寝時と最高值の位相時間掞よび起床時・就寝時 と最高値の舌下温の差の日内变動特性は生活習慣と同様 に個人差が大きかった。精神的側面 QOLサマリースコ アの高值群は, 起床時舌下温および舌下温の最高值が高 く, 最高值が出現する時刻が早く, 起床時から最高值の 位相時間が短いことが明らかになった。つまり，精神的 な健康度が高い者は, 日内変動特性に優れることを示し ている。 また，精神的健康度の高い者に扔ける生活習慣 の特徵は, 朝食を摂取し, 1 日 3 食の規則的な食事習慣, 1 日 6 時間以上の良好な睡眠習慣，運動習慣を有してお り，不定愁訴の有訴率が低いことである．SF-36v2の下 位尺度の結果から, 舌下温の日内変動特性は, 全体的健 康感，日常役割機能（精神）および心の健康との関連性 が顕著であり，精神的健康度を特に反映するものと考え る. 以上のことから, 男子大学生の舌下温の日内変動特 性，生活習慣と精神的健康度に関連性が確認された。こ のことから，日常生活に扔ける午前中の光暴露，朝食の 摂取, 朝の軽運動など概日リズムの同調因子を意識し, 良好な生活習慣を獲得することは, 強弱の明確な概日リ ズムの獲得, 精神的健康度を高める要因の 1 つであるも 
のと考察する.

$$
\text { まとめ }
$$

本研究は, 男子大学生を対象に HRQOL と舌下温の日 内変動特性, 生活習慣および不定愁訴の関連性を検討し, 以下の知見が示された。

1. 精神的側面QOLサマリースコアで群分けした体温 の日内変動特性は, 起床時舌下温, 舌下温の最高值, 起 床時と最高值の差に有意な差が観察されることが明らか になった。

2. 身体的側面QOLサマリースコアおよび役割／社会 的側面 QOL サマリースコアの高低と舌下温の日内変動 特性に明確な関連性は観察されなかった。

3. 身体的側面および精神的側面 QOLサマリースコア の高い群は, 良好な生活習慣を有し, 不定愁訴の発現率 が低いことが明らかになった。

本研究の主な知見は, 男子大学生の舌下温の日内変動 特性, 生活習慣, 精神的健康度に関連性が存在すること を明らかにしたことである。このことは，舌下温の日内 変動特性が精神的健康度を反映することを示唆する。ま た, 同調因子は, 精神的健康度を高め, 不定愁訴を軽減 させる要因である可能性がある.

利益相反自己申告：申告すべきものはなし

\section{謝 辞}

本研究を遂行するにあたり，多大な御協力を頂きました 対象者各位に心より感謝申し上げます。また, 本研究は, 科 学研究費助成事業（課題番号：15K21546）の支援を受け, 実施された。

\section{引用文献}

1）田原 優：時間栄養学一食事内容とタイミングー, 体育 の科学, 65: 889-894, 2015.

2) Weinert D, Waterhouse J. The circadian rhythm of core temperature: effects of physical activity and aging. Physiol Behav 90: 246-256, 2007.

3）山口英峰, 関和俊, 高原皓全, 小野寺 昇, 永見邦篤: 日内 変動に打ける心臟自律神経系活動と反射機能との関倸, 健康医科学研究助成論文集, 24: 134-143, 2009.

4) Nishimura K, Nagasaki K, Yamaguchi H, Yoshioka A, Nose Y, Onodera S, Takamoto N. Circadian variations in anaerobic threshold. Kinesiology 46: 164-170, 2014.

5) Vandewalle G, Middleton B, Rajaratnam SM, Stone BM, Thorleifsdottir B, Arendt J, Dijk DJ. Robust circadian rhythm in heart rate and its variability: influence of exogenous melatonin and photoperiod. J Sleep Res 16: 148-155, 2007.

6) Czeisler CA, Duffy JF, Shanahan TL, Brown EN, Mitchell JF, Rimmer DW, Ronda JM, Silva EJ, Allan JS, Emens JS, Dijk DJ, Kronauer RE. Stability, preci- sion, and near-24-hour period of the human circadian pacemaker. Science 284: 2177-2181, 1999.

7) Honma K, Honma S, Wada T. Entrainment of human circadian rhythms by artificial bright light cycles. EXperientia 43: 572-574, 1987.

8) Tahara Y, Shibata S. Chronobiology and nutrition. Neuroscience 253: 78-88, 2013. doi: 10.1016/ j.neuroscience.2013.08.049.

9）野瀬由佳, 西村一樹, 山口英峰, 小野寺 昇：朝食摄取習 慣の有無が昼食後の舌下温, 心拍数及び自律神経系活動 に及ほすす影響, 川崎医療福祉学会誌, 22: 37-43, 2012.

10) Yamanaka Y, Honma K, Hashimoto S, Takasu N, Miyazaki T, Honma S. Effects of physical exercise on human circadian rhythms. Sleep Biol Rhythms 4: 199206, 2006. doi: 10.1111/j.1479-8425.2006.00234.x.

11) Yamanaka $Y$, Hashimoto $S$, Tanahashi $Y$, Nishide $S$, Honma S, Honma K. Physical exercise accelerates reentrainment of human sleep-wake cycle but not of plasma melatonin rhythm to 8-h phase-advanced sleep schedule. Am J Physiol Regul Integr Comp Physiol 298: R681-R691, 2009. doi: 10.1152/ajpregu.00345.2009.

12) Hashimoto S, Nakamura K, Honma S, Honma K. Nonphotic entrainment of human rest-activity cycle independent of circadian pacemaker. Sleep Biol Rhythms 2: 29-36, 2004. doi: 10.1111/j.1479-8425.2003.00078.x.

13) Aoki H, Yamada N, Ozeki Y, Yamane H, Kato N. Minimum light intensity required to suppress nocturnal melatonin concentration in human saliva. Neurosci Lett 252: 91-94, 1998.

14) Brainard GC, Hanifin JP, Greeson JM, Byrne B, Glickman G, Gerner E, Rollag MD. Action spectrum for melatonin regulation in humans: evidence for a novel circadian photoreceptor. J Neurosci 21: 6405-6412, 2001.

15) Khalsa SB, Jewett ME, Cajochen C, Czeisler CA. A phase response curve to single bright light pulses in human subjects. J Physiol 549 (Pt 3): 945-952, 2003.

16) Duffy JF, Dijk DJ, Klerman EB, Czeisler CA. Later endogenous circadian temperature nadir relative to an earlier wake time in older people. Am J Physiol 275 (5 Pt 2): R1478-R1487, 1998

17）太田龍朗：睡眠覚醒リズム障害とその治療, 精神医学, 31: 61-67, 1989.

18）三池輝久: 脳科学と教育と生活環境, 脳と発達, 38: 8591, 2006. doi: 10.11251/ojjscn1969.38.85.

19) Muller JE, Tofler GH, Stone PH. Circadian variation and triggers of onset of acute cardiovascular disease. Circulation 79: 733-743, 1989.

20) Pan A, Schernhammer ES, Sun Q, Hu FB. Rotating night shift work and risk of type 2 diabetes: two prospective cohort studies in women. PLoS Med 8: e1001141, 2011. doi: 10.1371/journal.pmed.1001141.

21）香川靖雄：時間栄養学による生活習慣病の予防,体力科 学, 63: 293-304, 2014. doi: 10.7600/jspfsm.63.293.

22）片山友子, 水野（松本）由子, 稲田 紘: 大学生の生活習 慣とメンタルヘルスの関連性, 総合健診, 41: 283-293, 2014. doi: 10.7143/jhep.41.283. 
23）竹上未紗, 福原俊一. SF-36活用編 誰も教えてくれな かったQOL活用法一測定結果を研究・診療・政策につ なげる, NPO 健康医療評価研究機構, 東京, 2010.

24) Fukuhara S, Bito S, Green J, Hsiao A, Kurokawa K. Translation, adaptation, and validation of the SF-36 Health Survey for use in Japan. J Clin Epidemiol 51: 1037-1044, 1998.

25) Fukuhara S, Ware JE Jr, Kosinski M, Wada S, Gandek B. Psychometric and clinical tests of validity of the Japanese SF-36 Health Survey. J Clin Epidemiol 51: 1045-1053, 1998.

26）福録恵子, 長野拓三, 荻野 敏：アトピー性皮膚炎患者に おけるQOL：SF-36を用いて，アレルギー, 51：11591169, 2002.

27）吉矢邦彦, 蓮沼行人, 岡 伸俊, 大前博志, 守殿貞夫：透析 患者における QOLの評価 SF-36による健康関連 QOL,
日本透析医学会雑誌, 34: P201-P205, 2001

28）小西香苗, 百武愛子, 村松 宰：女子大学生における食事 パターンと健康関連 QOL との関連, 信州公衆衛生雑誌, 7: 83-94, 2013.

29）徳田完二：わが国の大学生の生活習慣と精神健康に関 わる研究の動向と課題, 立命館人間科学研究, 29: 95110, 2014.

30）小曾根基裕, 黒田彩子, 伊藤 洋 : 高齢者の不眠, 日本老 年医学会杂隹誌, 49: 267-275, 2012

31）熊谷雄治：生体リズム cosinor 法によるデー夕解析, 臨 床検査, 45: 594-600, 2001.

32) Kozaki T, Toda N, Noguchi H, Yasukouchi A. Effects of different light intensities in the morning on dim light melatonin onset. J Physiol Anthropol 30: 97-102, 2011. 